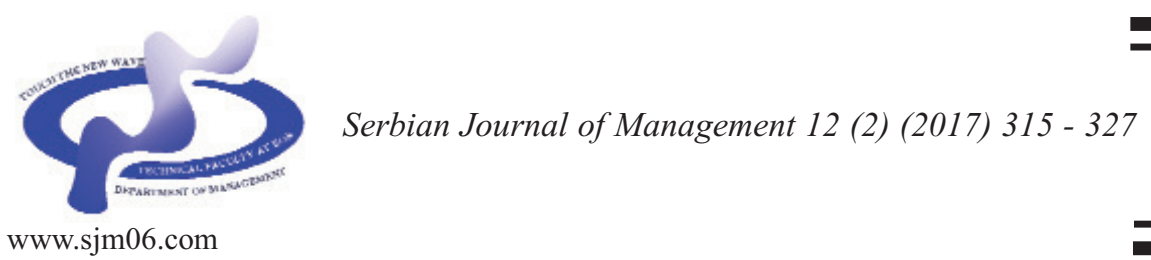

\title{
ECONOMIC AND ENVIRONMENTAL EFFECTS OF COLLECTION AND PRIMARY RECYCLING OF PACKAGING WASTE FROM HYGIENE AND CLEANING PRODUCTS IN SERBIA
}

\author{
Žarko Vranjanac* and Dragan Spasić \\ University of Niš, Faculty of Occupational Safety in Niš, \\ Čarnojevića 10A, 18000 Nišs, Serbia \\ (Received 06 October 2016; accepted 31 March 2017)
}

\begin{abstract}
Collection and primary recycling of packaging waste from hygiene and cleaning products occupy an important place in an integral waste management system. It is a fact that management of such waste helps reduce negative economic and environmental impact on one hand and helps bring direct and indirect benefits from collection and primary recycling of the packaging waste on the other hand. In order to obtain more comprehensive data on the economic effects of management of packaging waste from hygiene and cleaning products, this paper presents a methodology for calculating the relevant values associated with the waste. The paper also provides data on the amount, type, and market value of packaging waste from hygiene and cleaning products. Using the data on economic and environmental impact of the packaging waste from hygiene and cleaning products, as well as the data on economic benefits from this type of waste, it is possible to analyse the profitability of its collection and primary recycling in Serbia.
\end{abstract}

Keywords: hygiene and cleaning products, economic effects, environmental impact, packaging waste value and economic effects

\section{INTRODUCTION}

Packaging waste from hygiene and cleaning products (plastic bags and bottles, bottle caps, cardboard and plastic boxes, etc.) should not be scattered around the environment but deposited at predetermined locations in compliance with local or national legislation. When hygiene and cleaning products are used up, their packaging most often ends up in the bin with other waste, whether it is dry or wet municipal waste. However, raising the citizens' awareness that they should stop

\footnotetext{
* Corresponding author: zarko.vranjanac@znrfak.ni.ac.rs
}

DOI: $10.5937 / \mathrm{sjm} 12-11998$ 
throwing such packaging away into the environment, i.e. improperly disposing of it, and instead collect it and deposit it in an organized and proper fashion can have a significant positive environmental and economic impact (Inglezakis \& Moustakas, 2015). Positive environmental impact includes elimination of illegal dumping sites and increased ambient landscape aesthetics, e.g. removing the plastic bags, bottles, and cardboard, glass, and aluminium containers of hygiene and cleaning products. In addition, positive economic effects are also likely to occur (Theisen et al., 2012).

Economically, packaging waste from hygiene and cleaning products can have both negative and positive effects. Namely, such waste initially requires certain economic means to be managed properly, including the costs of collection, transport, storage, and treatment. In modern economies, this waste is treated as a potential resource, i.e. secondary raw material with a specific value that is constantly increasing (Brunner \& Fellner, 2007).

Analysis of the values of this type of waste involves establishing its real and hidden value.

The real value of packaging waste from hygiene and cleaning products is the one expressed as the product of the amount of a specific type of this waste and the average price of materials used to make the packaging. The hidden value of this waste is expressed as the sum of the costs of improper waste management, i.e. its improper disposal, costs of medical treatments of ill workers and civilians, and costs due to absenteeism of ill and injured workers (financial compensation, reduced production, etc.).

A comparison of these values with the degree of negative economic effects caused by improper management of this type of packaging waste can reveal whether such waste causes positive or negative economic effects. If the obtained real and hidden values exceed the costs of improper packaging waste management, taxes, and remediation and mitigation of the damage due to waste generation, it means that the effects are positive; otherwise, the effects are negative.

It should be noted that there were many families in Serbia that used to make a living by collecting and selling secondary raw materials. Nowadays, the only economic benefits of packaging waste collection are reaped by associations that deal exclusively with the collection of hygiene and cleaning products packaging waste. Thus, in Serbia there are associations dealing with organized collection of plastic caps, such as: "Čep za hendikep" (Eng. A Cap for the Handicapped) from Zrenjanin, "Čepom do osmeha" (A Cap for a Smile) from Novi Sad, "Pomoć ugroženima" (Help for Those in Need) from Niš, and others. Their exclusive collection of plastic caps from plastic hygiene and cleaning product containers creates a significant positive environmental and economic impact. Vranjanac, Ž. (2015).

Environmental impact of cap collection is reflected in a cleaner environment and reduced amount of plastic caps. For the sake of illustration, one tonne of plastic caps contains over five million pieces weighing 20 grams. Furthermore, these associations are able to collect sufficient amounts to be processed at the recycling centre.

The economic impact is reflected in specific financial results achieved through cap sales to recycling centres at prices ranging from 150 to 200 euros. The associations usually spend their earnings on orthopaedic aids, e.g. wheelchairs (Vranjanac \& Spasić, 2016). 


\section{METHODOLOGY}

Analysis of solid waste from hygiene and cleaning products can be performed using a variety of methods. For the research of such waste at the recycling centre of the Public Utility Company (PUC) "Mediana" in Niš, Serbia, the following methods were used (Vujić \& Brunner, 2009):

- direct analysis, or sample-and-sort method,

- indirect analysis of the composition of solid waste by means of analysing market products, and

- indirect analysis of the products of solid waste treatment.

Direct analysis of solid waste from hygiene and cleaning products involves the following steps:

- collecting samples for analysis that are smaller than the total amount of generated municipal solid waste of a particular hygiene and cleaning product,

- inspection and analysis of solid waste samples, and

- determination of waste resources and their substances.

Indirect analysis of the composition of municipal solid waste through the analysis of market products, which is applied to the analysis of the composition of packaging waste from hygiene and cleaning products, involves the gathering of:

- information about the hygiene and cleaning products manufacture,

- information about the fate of hygiene and cleaning products during use and consumption,

- information about the hygiene and cleaning products from the manufacturers, corporations, professional organizations (e.g.
A.I.S.E. - International Association for Soaps, Detergents and Maintenance Products), and government agencies (e.g. Serbian Environmental Protection agency)

- information about import, export, and supplies of every category of the analysed sample of solid waste from hygiene and cleaning products, and

- information about the average life span of a specific product.

Indirect analysis of the products of packaging waste treatment is based on the information about the resulting products after the treatment (recycling, disposal, incineration, etc.) of collected samples of this waste. The advantage of using this method lies in the fact that the outputs of hygiene and cleaning products waste treatment are less heterogeneous than its inputs (Vujić \& Brunner, 2009).

The use of the aforementioned methods for hygiene and cleaning products solid waste analysis is shown in Figure 1.

\subsection{Method of decursive calculation of economic effects}

Calculation of the economic effects of collection and primary recycling of solid waste from hygiene and cleaning products using the decursive method is made $a$ posteriori, after the manufacturing process, trade, and use of the products, and the registered economic and environmental impact caused by improper management of this waste (Spasić, 2003).

Comparison of the data on packaging waste values with the degree of negative economic impact resulting from improper management of this waste can yield the following relations:

- if the value of the packaging waste 


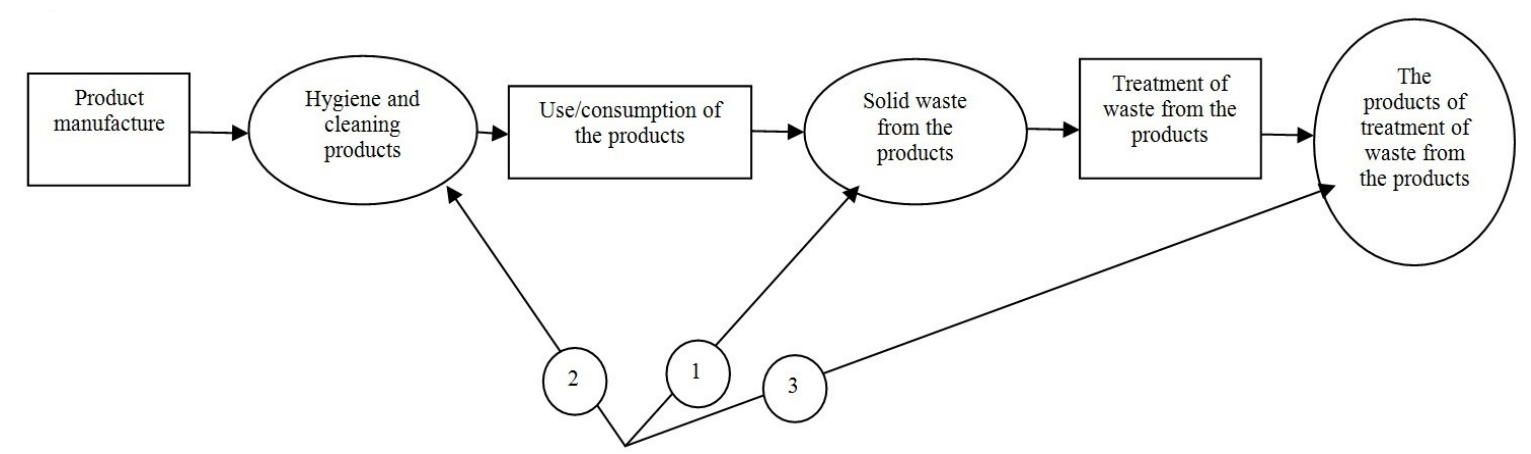

Figure 1. Methods of analysis of solid waste from hygiene and cleaning products: 1) Direct analysis, 2) Analysis of hygiene and cleaning products, 3) Analysis of the products of hygiene and cleaning products waste treatment (Vujić \& Brunner, 2009)

from hygiene and cleaning products is higher than the negative economic effects of improper waste management, the economic effects of collection and primary recycling are positive;

- if the value of the packaging waste from hygiene and cleaning products is lower than the negative economic effects of improper waste management, the economic effects of collection and primary recycling are negative.

2.2. Method of analysing economic and environmental justifiability of the collection and primary recycling of hygiene and cleaning products packaging waste at the recycling centre of the Public Utility Company "Mediana" in Niš, Serbia

During the month of June 2014, hygienic and cleaning products waste was collected from 600 households from larger urban (Niš, Pirot, Knjaževac, Kruševac, Jagodina, and Vranje) and rural areas in Central Serbia. The households that agreed to participate were asked to separate the waste from hygiene and cleaning products used by every household member over one month into previously prepared waste bags. The collected waste was transported to the recycling centre of the Public Utility Company "Mediana" Niš with specialized vehicles for packaging waste collection and transport.

The recycling centre of PUC "Mediana" Niš opened in 2014 with the capacity of 15 tonnes of waste per day. The centre does not process waste, but only separates different types of waste and packaging, for which it employs 20 workers. As part of its operation, the recycling centre has completed several projects aimed at improving waste management system in urban areas. One such project was Waste, which was financed by the EU via the IPA cross-border cooperation programme between Serbia and Bulgaria. The goal of the project was to provide adequate infrastructure for recyclable waste collection in the City of Niš (Pejčić \& Vranjanac, 2016).

The morphological composition of collected hygiene and cleaning products waste and its quantity was determined using the direct analysis method, also known as the sample-and-sort method. Samples were collected, inspected, and analyzed in order to determine their morphological composition, which was determined based on available data obtained through this research, for households or cities with the average 
standard of living. All 600 collected waste contents of different types of packaging were sorted into appropriate groups of packaging waste according to the type of packaging material.

The first stage involved hygienic and cleaning products waste sorting according to the type of packaging material:

- aluminium,

- glass,

- plastic, and

- paper and cardboard.

Aluminium is used as packaging for deodorants, shaving foams, and certain house cleaning products. Glass is used for perfumes, face skin products, and antiperspirants (roll-ons). Plastic packaging is the most common and it is used for a wide variety of products, from soaps, softeners, and laundry detergents, through face and body care products, to household care and auxiliary products. Paper and cardboard are used for almost every hygienic and cleaning product, often as additional packaging for perfumes, sets, powders, toothpastes, and household care products.

The core physical properties of hygienic and cleaning products waste are mass and volume. In the second stage the mass and volume of each of the 600 samples were measured. To measure the mass of the samples and their content in the environment, electronic platform scales with one load cell were used. The volume was measured by means of a graduated cylinder, a funnel, and auxiliary containers with different volumes depending on their content (larger containers were used for larger samples and vice versa).

\section{RESULTS}

Composition of solid waste from hygiene and cleaning products was determined by means of analysis of the composition of packaging material after primary recycling. The following values for the analysed waste were obtained (Pejčić \& Vranjanac, 2016):

- type of packaging according to the material,

- $\quad$ packaging mass, and

- packaging volume.

Table 1 shows the data on the mass and volume of packaging waste from hygiene and cleaning products according to the type of packaging material.

The analysis considered total mass and volume of the packaging from hygiene and cleaning products, as well as the amount of their content. The amount of packaging waste depends on the packaging material. The results showed that plastic packaging had the biggest mass percentage of the four

Table 1. Mass and volume of packaging according to the type of material in hygiene and cleaning products waste collected from 600 households (Pejčić \& Vranjanac, 2016)

\begin{tabular}{clllll}
\hline \multirow{2}{*}{ Number } & PACKAGING & MASS & \multicolumn{3}{c}{ VOLUME } \\
\cline { 3 - 6 } & MATERIAL & {$[\mathbf{k g}]$} & $\mathbf{\%}$ & {$\left[\mathbf{d m}^{\mathbf{3}}\right]$} & $\mathbf{\%}$ \\
\hline 1. & Plastic & 158.71 & 46 & $1,687.42$ & 48 \\
2. & Glass & 118.72 & 34 & $1,107.69$ & 32 \\
3. & Aluminium & 42.16 & 12 & 397.58 & 11 \\
4. & Paper and & 28.93 & 8 & 301.57 & 9 \\
& $\begin{array}{l}\text { cardboard } \\
\text { TOTAL }\end{array}$ & 348.52 & 100 & $3,494.26$ & 100 \\
\hline
\end{tabular}


categories with $46 \%$. It was followed by glass packaging with $34 \%$, aluminium packaging with $12 \%$, and paper and cardboard packaging with only $8 \%$ of the total packaging waste mass. The analysed waste did not contain any packaging made of wood (Pejčić \& Vranjanac, 2016).

Analysis of the volume of hygienic and cleaning products packaging waste, which had been classified according to the packaging material, showed that plastic packaging had the biggest volume percentage of the four categories with $48 \%$. It was followed by glass packaging with $33 \%$, aluminium packaging with $11 \%$, and paper and cardboard packaging with only $9 \%$ of the total packaging waste volume (Pejčić \& Vranjanac, 2016).

\subsection{Value of packaging waste from hygiene and cleaning products}

In the secondary raw materials market, packaging waste from hygiene and cleaning products has its own value, expressed as its price. The price of packaging waste from hygiene and cleaning products is expressed in monetary units (dinars or euros), per unit mass $\left(\mathrm{kg}\right.$, $\mathrm{t}$, etc.) or unit volume $\left(\mathrm{dm}^{3}\right.$ or $\left.\mathrm{m}^{3}\right)$. The total price of packaging waste from hygiene and cleaning products $\left(\mathrm{C}_{\text {ohs }}\right)$ expressed in suitable units of measure $(€ / \mathrm{kg}$, $€ / \mathrm{t}, € / \mathrm{dm}^{3}$, etc.) is calculated with the formula:

$$
\mathrm{C}_{\mathrm{ohs}}=\mathrm{C}_{\mathrm{p}}+\mathrm{C}_{\mathrm{s}}+\mathrm{C}_{\mathrm{m}}+\mathrm{C}_{\mathrm{pk}}+\mathrm{C}_{\mathrm{d}}+\mathrm{C}_{\mathrm{o}}
$$

where:

$\mathrm{C}_{\mathrm{p}}$ - price of plastics from hygiene and cleaning products waste;

$\mathrm{C}_{\mathrm{s}}$ - price of glass from hygiene and cleaning products waste;

$\mathrm{C}_{\mathrm{m}}$ - price of metals from hygiene and cleaning products waste;

$\mathrm{C}_{\mathrm{pk}}$ - price of paper and cardboard from hygiene and cleaning products waste;

$\mathrm{C}_{\mathrm{d}}$ - price of wood from hygiene and cleaning products waste;

$\mathrm{C}_{\mathrm{o}}$ - price of other materials from hygiene and cleaning products waste.

\subsection{Price of plastics from hygiene and cleaning products waste}

The price of plastics from hygiene and cleaning products waste $\left(\sum \mathrm{C}_{\mathrm{p}}\right)$ is determined according to the type of plastic. It is calculated as the sum of the products of prices and amounts of plastic subtypes, according to the formula:

$$
\begin{aligned}
& \sum \mathrm{C}_{\mathrm{p}}=(\mathrm{C} \times \mathrm{Q})_{\mathrm{pet}}+(\mathrm{C} \times \mathrm{Q})_{\mathrm{hdpe}}+(\mathrm{C} \times \mathrm{Q})_{\mathrm{pvc}} \\
& +(\mathrm{C} \times \mathrm{Q})_{\text {ldpe }}+(\mathrm{C} \times \mathrm{Q})_{\mathrm{pp}}+(\mathrm{C} \times \mathrm{Q})_{\mathrm{ps}}+ \\
& (\mathrm{C} \times \mathrm{Q})_{\mathrm{ost}}
\end{aligned}
$$

where:

$\mathrm{C}_{\text {pet }}$ and $\mathrm{Q}_{\text {pet }}$ - price and amount of polyethylene terephthalate plastic,

$\mathrm{C}_{\mathrm{hdpe}}$ and $\mathrm{Q}_{\mathrm{hdpe}}$ - price and amount of highdensity polyethylene plastic,

$\mathrm{C}_{\mathrm{pvc}}$ and $\mathrm{Q}_{\mathrm{pvc}}$ - price and amount of polyvinyl chloride plastic,

$\mathrm{C}_{\text {ldpe }}$ and $\mathrm{Q}_{\text {ldpe }}$ - price and amount of lowdensity polyethylene plastic,

$\mathrm{C}_{\mathrm{pp}}$ and $\mathrm{Q}_{\mathrm{pp}}$ - price and amount of polypropylene plastic,

$\mathrm{C}_{\mathrm{ps}}$ and $\mathrm{Q}_{\mathrm{ps}}$ - price and amount of polystyrene plastic, and

$\mathrm{C}_{\text {ost }}$ and $\mathrm{Q}_{\text {ost }}$ - price and amount of other types of plastic. 
3.3. Price of glass from hygiene and where: cleaning products waste

The price of glass from hygiene and cleaning products waste $\left(\sum \mathrm{CQ}_{\mathrm{ST}}\right)$ is determined according to the type of glass. It is calculated as the sum of the products of prices and amounts of glass subtypes, according to the formula:

$\sum \mathrm{CQ}_{\mathrm{ST}}=(\mathrm{C} \times \mathrm{Q})_{\mathrm{B}}+(\mathrm{C} \times \mathrm{Q})_{\mathrm{Z}}+(\mathrm{C} \times \mathrm{Q})_{\mathrm{S}}$

where:

$\mathrm{C}_{\mathrm{m}}$ and $\mathrm{Q}_{\mathrm{m}}$ - price and amount of soft aluminium packaging,

$\mathrm{C}_{t}$ and $\mathrm{Q}_{t}$ - price and amount of hard aluminium packaging.

\subsection{Price of paper and cardboard packaging}

The price of paper and cardboard packaging $\left(\sum \mathrm{CQ}_{\mathrm{PIK}}\right)$ is determined according to the type of material. It is calculated as the sum of the products of prices and amounts of $\mathrm{C}_{\mathrm{B}}$ and $\mathrm{Q}_{\mathrm{B}}$ - price and amount of colourless glass packaging, $\mathrm{C}_{\mathrm{Z}}$ and $\mathrm{Q}_{\mathrm{Z}}$ - price and amount of green glass packaging,

$\mathrm{C}_{\mathrm{S}}$ and $\mathrm{Q}_{\mathrm{S}}$ - price and amount of amber glass packaging. either paper or cardboard, according to the formula:

$$
\sum(\mathrm{CQ})_{\mathrm{PIK}}=(\mathrm{C} \times \mathrm{Q})_{\mathrm{p}}+(\mathrm{C} \times \mathrm{Q})_{\mathrm{k}}
$$

where:

\subsection{Price of aluminium packaging}

The price of aluminium packaging $\left(\sum \mathrm{CQ}_{\mathrm{AL}}\right)$ is determined according to the type of aluminium. It is calculated as the sum of the products of prices and amounts of aluminium subtypes, according to the formula:

$\sum(\mathrm{CQ})_{\mathrm{AL}}=(\mathrm{C} \times \mathrm{Q})_{\mathrm{m}}+(\mathrm{C} \times \mathrm{Q})_{\mathrm{t}}$

(4) obtained from the companies that buy or sell

Table 2. Price of packaging waste according to the material used, in Serbia, in euro/kg (Price report - SanSI Marketing System, 2014)

\begin{tabular}{ll}
\hline Packaging & Price in euro/kg \\
\hline Aluminium, soft and hard & $\mathbf{0 . 8 4}-\mathbf{1}$ \\
HDPE & $\mathbf{0 . 2 3}-\mathbf{0 . 9 6}$ \\
LDPE & $\mathbf{0 . 2 6}-\mathbf{0 . 8 0}$ \\
Mixed paper and cardboard & $\mathbf{0 . 0 6}-\mathbf{0 . 0 9}$ \\
PET & $\mathbf{0 . 1 8}-\mathbf{0 . 3 9}$ \\
PP & $\mathbf{0 . 2 3}-\mathbf{0 . 9 6}$ \\
PS & $\mathbf{0 . 4 7}-\mathbf{1 . 0 4}$ \\
PVC & $\mathbf{0 . 2 7}-\mathbf{0 . 5 5}$ \\
Glass & $\mathbf{0 . 0 5}-\mathbf{0 . 0 7}$ \\
\hline
\end{tabular}


secondary raw materials. The price of packaging waste from hygiene and cleaning products greatly depends on whether the waste was previously sorted, whether it was treated (ground, granulated, baled, etc.), and whether it contains any impurities. If it was sorted and treated, it is more expensive than the unsorted and untreated waste. The waste containing some impurities is far less expensive than 'pure' waste (Brunner \& Fellner, 2007).

The value of packaging waste from hygiene and cleaning products can be calculated based on the data on the amount collected and deposited daily, monthly, and annually, and by including the percentage of constituent materials as well as the price of the waste in the secondary raw materials market.

If it is assumed that the total amount of generated packaging waste from hygiene and cleaning products has the same composition as the sample analysed in this research, it is possible to determine its value. The calculated daily, monthly, and annual value of packaging waste from hygiene and cleaning products in the Nišava County and in Serbia is shown in Table 3.

The daily, monthly, and annual values of waste from hygiene and cleaning products in Serbia reduced to the total population number indicate the values of this waste per capita in the same intervals. Namely, the value of waste from hygiene and cleaning
Table 4. Value of packaging waste from hygiene and cleaning products according to the material used, in euros

\begin{tabular}{cll}
\hline NUMBER & $\begin{array}{c}\text { PACKAGING } \\
\text { MATERIAL }\end{array}$ & $\begin{array}{c}\text { VALUE } \\
\text { [euro] }\end{array}$ \\
\hline 1. & Plastic & $4,008,219.77$ \\
2. & Glass & $71,675.77$ \\
3. & Aluminium & $1,855,136.70$ \\
4. & Paper and & $61,837.92$ \\
& cardboard & \\
& TOTAL & $5,996,870.16$ \\
\hline
\end{tabular}

products amounts to ca. 1 euro per capita annually. By using the percentage of the mass of specific packaging waste materials and their prices, the values for plastic, glass, aluminium, and paper and cardboard packaging waste can be calculated (Table 4, Figure 2).

Economic value of packaging waste from hygiene and cleaning products is reflected in the market value of such waste. Economic benefit can be viewed as the final value of a material in the secondary raw materials market, while it can also be viewed through waste management stages, considering that waste management reduces the costs incurred by the negative environmental and health impact of the waste.

Studies by other authors throughout the world analyze the possibility of utilizing household waste for energy generation purposes, e.g. for heating (Doležalová et al., 2013), dealing with hazardous household waste management (Inglezakis \&

Table 3. Value of packaging waste from hygiene and cleaning products in the Nišava County and in Serbia in 2015 in euros

\begin{tabular}{lllll}
\hline \multirow{2}{*}{ SCOPE } & NUMBER OF & \multicolumn{3}{c}{$\begin{array}{c}\text { PRICE } \\
\text { [euro] }\end{array}$} \\
\cline { 3 - 5 } & HOUSEHOLDS & DAY & MONTH & YEAR \\
\hline This research & 600 & 4.04 & 120.55 & $1,446.29$ \\
Nišava County & 127,300 & 852.38 & $25,570.65$ & $306,847.52$ \\
Serbia & $2,487,886$ & 16,658 & $499,739.21$ & $5,996,870.16$ \\
\hline
\end{tabular}




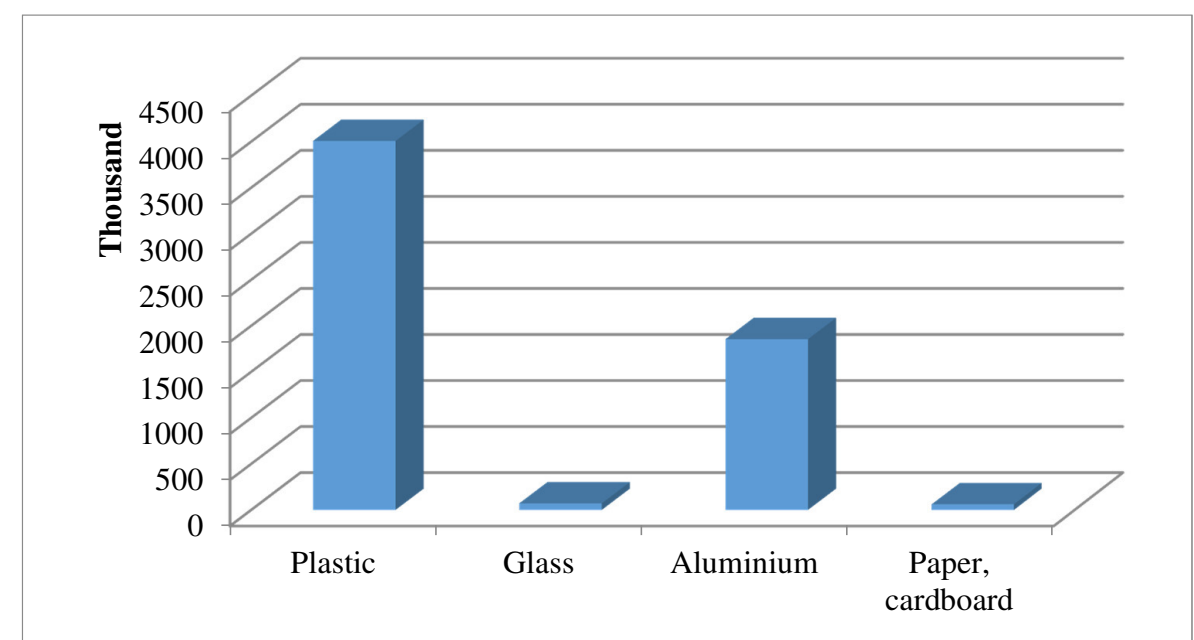

Figure 2. Annual value of packaging waste from hygiene and cleaning products according to the materials used, in thousand euros

Moustakas, 2015), or setting waste priorities in developing countries (Brunner \& Fellner, 2007). On the other hand, the study presented in this paper provides concrete economic prices of hygiene and cleaning products waste collected from households in Serbia, so a comparison with the aforementioned similar studies would not be adequate. The studying of packaging waste from hygiene and cleaning products in terms of its environmental and economic significance is a new reach for this field of science, as this issue has thus far been given little attention both in literature and in practice, so this paper can be considered relevant for the international scientific community.

The classification of economic values of packaging waste from hygiene and cleaning products is shown in Figure 3 (Vranjanac \& Spasić, 2016).

Total material economic values of packaging waste from hygiene and cleaning products ( $\sum$ EKohs) are calculated with the formula:

$\sum \mathrm{EK}_{\mathrm{ohs}}=\mathrm{EK}_{\mathrm{d}}+\mathrm{EK}_{\mathrm{i}}$

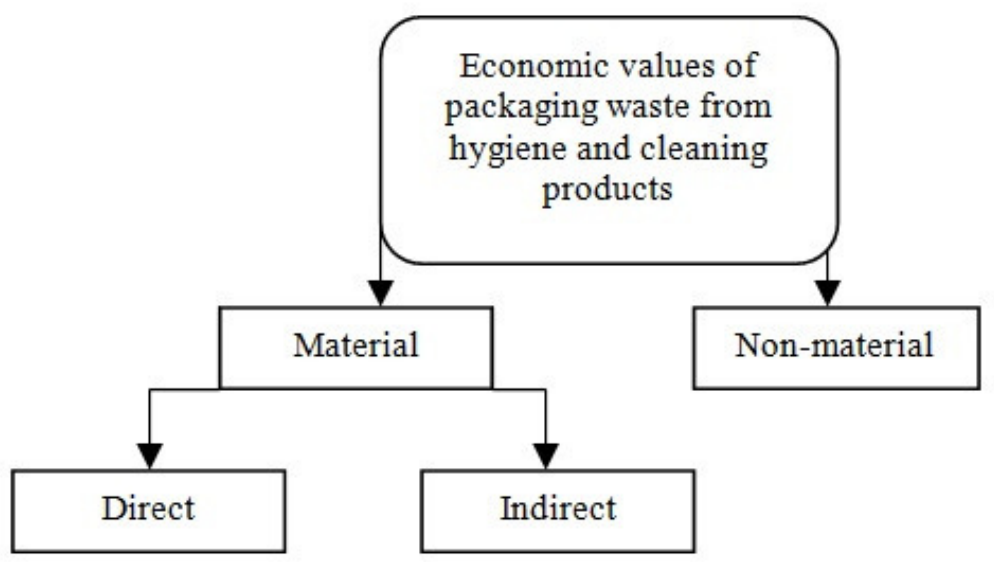

Figure 3. Classification of economic values of packaging waste from hygiene and cleaning products (Vranjanac \& Spasić, 2016) 
where:

$E_{d}$ - direct value of packaging waste from hygiene and cleaning products,

$\mathrm{EK}_{\mathrm{i}}$ - indirect value of packaging waste from hygiene and cleaning products.

Direct economic value of packaging waste from hygiene and cleaning products depends on the amount and type of packaging and the material used to make the packaging. The amount of packaging waste is expressed in measuring units for waste mass, most commonly in kilograms $[\mathrm{kg}]$ or tonnes [t], and measuring units for waste volume - cubic decimetres [dm3] or cubic metres [m3]. The price of packaging waste is dictated by the secondary raw materials market (see Table 2), but also by the possibility of its processing, use as an energy source, or reuse. The waste price is expressed in euros (see Tables 3 and 4).

Indirect economic value of packaging waste from hygiene and cleaning products is reflected in environmental protection, freeing up of space for profitable activities, and healthcare. Proper management of packaging waste from hygiene and cleaning products can contribute to avoiding its negative environmental and health impact and thus significantly conserve material assets. In addition, the economic benefit can initially be invisible. For instance, deposited waste from hygiene and cleaning products occupies a lot of space. With proper waste management, it would be deposited over a much smaller area, which, in turn, would allow other profitable activities to be conducted in the remaining area. Because these economic effects are only visible after a specific period of time, they constitute the indirect economic value of packaging waste from hygiene and cleaning products, which requires long-term monitoring and analysis (Vranjanac \& Spasić, 2016).

Non-material economic value of packaging waste from hygiene and cleaning products involves aesthetic, ambient, and landscape values, which are not expressed materially. These values should be given more attention, both because of the population occupying a given area and because of tourism development. When a poorly organized waste management system is in place, cities tend to resemble dumpsites, so population migrations tend to increase. This is corroborated by the fact that the price of a square meter of residential space is lower in cities with inadequate waste management, which ultimately leads to environmental pollution and poses a threat to human health (Vujić \& Brunner, 2009).

In fact, if there were no adequate waste management for waste from hygiene and cleaning products, cities would turn into dumpsites and diseases, injuries, and fatalities would abound, which would eventually lead to an economic collapse (Inglezakis \& Moustakas, 2015). Recovery of a degraded environment is a long and economically demanding process, as is medical treatment of humans. In addition, economic consequences begin with the generation of waste, and continue with its collection, transport, storage, processing, and its final disposal. Thus, economic consequences follow the course of management of hygiene and cleaning products packaging waste and also include the costs incurred by negative environmental and human health impact (Vranjanac, 2016). Management of this type of waste requires qualified personnel, from the engineers versed in public utility jobs and specially trained for waste management to technicians and operators performing specific tasks. 
Workforce cost is determined based on the planned number of employees and their average gross monthly income. This cost is significant for waste management, so it will be analyzed in more detail below (Vranjanac \& Spasić, 2016).

\subsection{Number of employees in waste management in Serbia}

The number of employees hired for waste disposal from 2003 to 2007 is given in Table 5 and Figure 4.

Table 5. Number of employees for waste disposal in Serbia from 2003 to 2007 (Statistical Yearbook of Serbia, 2003-2007)

\begin{tabular}{lll}
\hline Year & No. of employees & Index \\
\hline 2003 & 11,388 & 100.00 \\
2004 & 11,669 & 102.47 \\
2005 & 12,153 & 106.71 \\
2006 & 12,388 & 108.78 \\
2007 & 12,596 & 110.60 \\
\hline
\end{tabular}

The data reveal that the number of employees in waste disposal increased annually, by $10.6 \%$ in total, from 11,388 employees in 2003 to 12,596 in 2007.

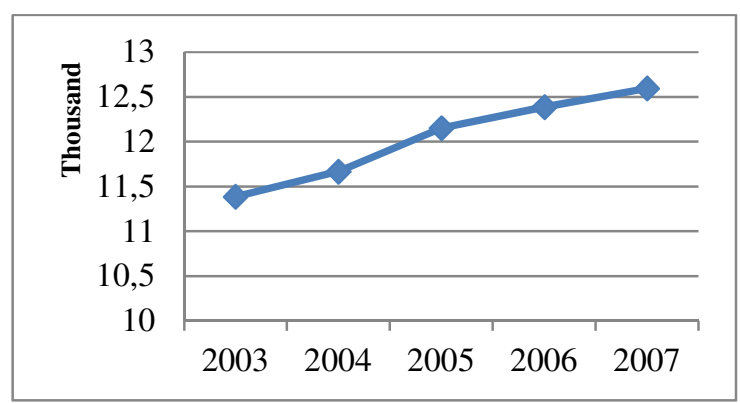

Figure 4. Flow of the number of employees in waste disposal in Serbia from 2003 to 2007

In 2009, the job category of waste disposal changed its name to waste collection, treatment, and disposal. The number of employees in waste collection,
Table 6. Number of employees in waste collection, treatment, and disposal in Serbia from 2009 to 2013 (Statistical Yearbook of Serbia, 2009-2013)

\begin{tabular}{lll}
\hline Year & No. of employees & Index \\
\hline 2009 & 14,505 & 100.00 \\
2010 & 14,285 & 98.48 \\
2011 & 14,370 & 99.07 \\
2012 & 14,615 & 100.76 \\
2013 & 15,786 & 108.83 \\
\hline
\end{tabular}

treatment, and disposal from 2009 to 2013 is given in Table 6 and Figure 5.

The data revealed that the number of employees in waste collection, treatment, and disposal in the shown five-year period increased by $8.83 \%$, from 14,505 in 2009 to 15,786 in 2013.

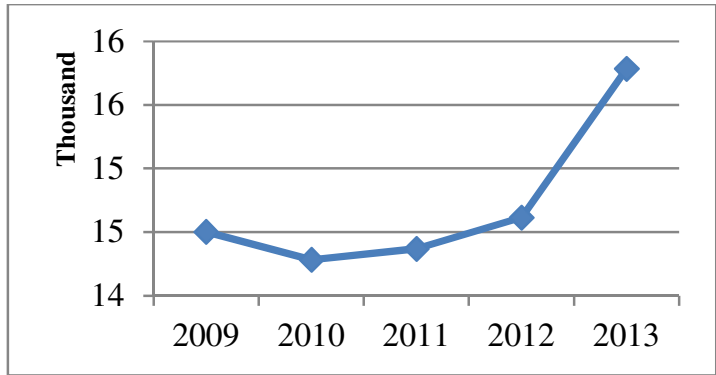

Figure 5. Flow of the number of employees in waste collection, treatment, and disposal in Serbia from 2009 to 2013

\subsection{Waste management workforce cost in Serbia}

Cost of the workforce in waste management in Serbia is expressed through gross or net incomes. The following formula calculates the cost of workforce expressed through gross income $\left(\mathrm{TRS}_{\mathrm{bz}}\right.$ ) (Vranjanac and Spasic, 2017):

$\mathrm{TRS}_{\mathrm{bz}}=\mathrm{Z} \times \mathrm{PBZ}$ 
where:

$\mathrm{Z}$ - number of employees and

PBZ - average gross income.

The following formula calculates the cost of workforce expressed through net income (TRSnz):

$\mathrm{TRS}_{\mathrm{nz}}=\mathrm{Z} \times \mathrm{PNZ}$

where:

$\mathrm{Z}$ - number of employees and

$\mathrm{PNZ}$ - average net income.

The data on the number of employees, gross and net incomes, and workforce cost for waste management in Serbia from 2009 to 2013 are shown in Table 7 and Figure 6.

The data revealed that the workforce cost for waste management within this period increased significantly, with the gross cost as much as $41.4 \%$ higher, from 4,757,785.05 euros in 2009 to $6,730,045.38$ euros in 2013. A similar increase occurred with the net workforce costs for waste management, which increased by as much as $42.6 \%$, from $3,409,835.40$ euros in 2009 to $4,864,140.18$ euros in 2013.

\section{CONCLUSION}

Based on the study presented in this paper, it is recommended that the collection and primary recycling of packaging waste

Table 7. Number of employees, gross and net incomes, and workforce cost for waste management in Serbia from 2009 to 2013, in euros (Statistical Yearbook of Serbia, 20092013)

\begin{tabular}{llllll}
\hline Year & $\begin{array}{l}\text { No. of } \\
\text { employees }\end{array}$ & $\begin{array}{l}\text { Average gross } \\
\text { income per } \\
\text { employee }\end{array}$ & $\begin{array}{l}\text { Average net } \\
\text { income per } \\
\text { employee }\end{array}$ & $\begin{array}{l}\text { Gross } \\
\text { workforce cost }\end{array}$ & $\begin{array}{l}\text { Net workforce } \\
\text { cost }\end{array}$ \\
\hline 2009 & 14,505 & 328.01 & 235.08 & $4,757,785.05$ & $3,409,835.40$ \\
2010 & 14,285 & 346.09 & 248.69 & $4,943,895.65$ & $3,552,536.65$ \\
2011 & 14,370 & 379.22 & 273.65 & $5,449,391.40$ & $3,932,350.50$ \\
2012 & 14,615 & 410.03 & 295.40 & $5,992,588.45$ & $4,317,271.00$ \\
2013 & 15,786 & 426.33 & 308.13 & $6,730,045.38$ & $4,864,140.18$ \\
Total & 73,561 & & & $27,873,705.93$ & $20,076,133.73$ \\
\hline
\end{tabular}

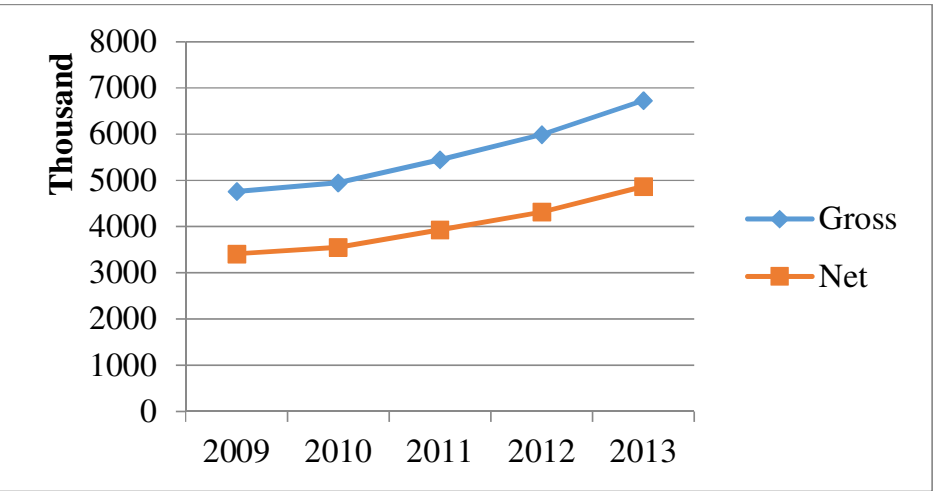

Figure 6. Flow of gross and net workforce cost for waste management in Serbia from 2009 to 2013 in thousand euros (Statistical Yearbook of Serbia, 2009-2013) 
from hygiene and cleaning products be conducted in an environmentally acceptable and economically affordable manner, which would yield positive effects on the society. This would require a special way of managing packaging waste from hygiene and cleaning products as a separate category of waste, which plays an important role in sustainable waste management. The key is to conduct collection and primary recycling, because, on the one hand, it is the only way to avoid unwanted environmental impact and, on the other hand, it is a way to save time for separating different, economically significant, packaging materials. Otherwise, improper treatment of packaging waste from hygiene and cleaning products can cause significant negative environmental and health impact, with the added economic effects.

Positive economic effects of hygiene and cleaning products waste management occur when the economic effects do not exceed economic benefits and investment in the management of such waste.

Negative economic effects of hygiene and cleaning products waste management occur when the economic effects of improper waste management exceed economic benefits and investment in assets and equipment for waste management. This difference can be 'balanced out' by reducing unwanted environmental impact or through so-called indirect and non-material benefits from hygiene and cleaning products waste, whose values are difficult to express in practice.

The most relevant results obtained from this study pertain to the annual value of packaging waste from hygiene and cleaning products in Serbia, which amounts to $5,996,870.16$ euros, of which plastic packaging constitutes 4,008,219.77 euros, glass packaging 71,675.77 euros, aluminium packaging 1,855,136.70 euros, and paper and cardboard packaging $61,837.92$ euros. In addition, this manner of collection and primary recycling completely eliminates the unwanted effects on the environment while producing positive economic effects. Through a comparison of workforce net income in Serbia for 2013, which amounts to $4,864,140.18$ euros, with the annual value of packaging waste from hygiene and cleaning products, it can be concluded that the value of this type of waste covers the net expenses for managing all types of waste and simultaneously generates revenue of $1,132,729.98$ euros.

Investment in hygiene and cleaning products waste management increases the costs, but also raises the price of waste in the secondary raw materials market with each waste management stage. The presence of economic effects that are not instantly visible, but take time to manifest themselves, together with the indirect and non-material benefits, makes investing in hygiene and cleaning products packaging waste management economically and environmentally justified.

\section{References}

Brunner, P., \& Fellner, J. (2007). Setting priorities for waste in developing countries. Waste Management \& Research, 25, 234240.

Doležalová, M., Benešová, L., \& Závodská, A. (2013). The changing character of household waste in the Czech Republic between 1999 and 2009 as a function of home heating methods, Waste management, 33 (9), 1951-1957.

Inglezakis, V., \& Moustakas, K. (2015). 
Household hazardous waste management: A review. Journal of Environmental Management, 150, 310-321.

Pejčić, D., \& Vranjanac, Ž. (2016). Environmental impact analysis of hygiene and cleaning products packaging waste, Safety engineering, Faculty of occupational safety in Nish, 21-27.

Price report. (2014). SanSI Marketing System, Belgrade, Serbia.

Spasić, D. (2003). Economics of Occupational Safety, Grafika Galeb, Niš, Serbia. (In Serbian)

Statistical Yearbook of Serbia. (20092013). Republic Institute for Statistics in Belgrade, Belgrade, Serbia.

Theisen, H., Vigil, S., \& Tchobanoglous, G. (2012). Integrated solid waste management, Engineering Principles and Management Issues, McGraw-Hill Inc., 212225.

Vranjanac, Ž., \& Spasić, D. (2017). Waste management workforce cost analysis in Serbia from 2009 to 2015, Ekonomika, Society of economists, 63 (2), 105-112. (In Serbian).

Vranjanac, Ž., \& Spasić, D. (2016). Economic Effects of Collection and Primary Recycling of Packaging Waste from Hygiene and Cleaning Products in Serbia, 6th International Symposium on Environmental and Flow Management - EMFM 2016, Bor, Serbia, 106-118.

Vranjanac, Ž. (2015). EconomicEnvironmental Impact of Household care Products on the environment. Master's thesis, Faculty of Occupational Safety in Nis, Nis, Serbia. (In Serbian)

Vranjanac, Ž. (2016). The management of hygiene and cleaning products packaging waste, XII Internacional May Conference on Strategic Management - IMKSM 2016, Bor, Serbia, 790-798.
Vujić, G., \&, Brunner, P. (2009). Sustainable Waste Management, Faculty of Technical Science, Novi Sad, Serbia. (In Serbian) 